\title{
EFFECT OF TREATMENT WITH THYROXINE ON THE ACETYLCHOLINE CONTENT OF RAT HEART
}

\author{
N.K. KHANNA* and P. PANDHI \\ Department of Pharmacology, S.N. Medical College, Jodhpur, Rajasthan, India
}

Received for publication November 11, 1971

An increase in the catecholamine content of the hearts from thyroxine-treated rabbits has recently been reported (I) and it has been suggested that some of the signs of the hyperthyroid state can be attributed to increased activity of the sympathetic nervous system $(2,3)$. No attention has been given, however, to the role of acetylcholine during hyperthyroid state, although the endogenous production of acetylcholine is known to be essential for normal physiological function of the heart $(4,5)$. It is therefore of interest to determine the changes of acetylcholine content of rat hearts which have been treated with thyroxine.

Forty-one albino rats of both sexes, weighing between 90 and $130 \mathrm{~g}$, were divided into 2 groups. Animals in the first group served as control and were not given any drugs. The second group was given 1-thyroxine sodium, $2 \mathrm{mg} / \mathrm{kg}$ intraperitoneally, once daily for three days. On the fourth day the animals were sacrificed by a blow on the head and the hearts removed and cleaned. The atria and ventricles were excised, weighed and utilized for estimation of acetylcholine content by the method of Anand (6). The extraction of acelylcholine like substance was carried out in $5 \mathrm{ml}$ eserinized Ringer solution at $\mathrm{pH} \mathrm{4}$, at a temperature of $90-100 \mathrm{C}$. The assay was done biologically on a frog's rectus abdominis muscle preparation.

As the results obtained indicate, thyroxine brings about a statistically significant increase in the atrial and ventricular content of acetylcholine (Table 1). Recently, evidence has accumulated to suggest that in an attempt to maintain the constancy of the internal environ-

TABLE 1. Effects of thyroxine on acetylcholine content of rat myocardium $(\mu \mathrm{g} / \mathrm{g}$ of fresh tissue).

\begin{tabular}{|c|c|c|c|c|c|c|c|}
\hline \multirow{2}{*}{ Procedure } & \multirow{2}{*}{$\begin{array}{l}\text { No. of } \\
\text { rats } \\
\text { used }\end{array}$} & \multicolumn{3}{|c|}{ Atrium } & \multicolumn{3}{|c|}{ Ventricle } \\
\hline & & Mean & $\pm \mathbf{S} . \mathrm{E}$ & P-value & Mean & \pm S.E. & P-value \\
\hline Control & 31 & 7.4 & 0.9 & - & 2.4 & 0.5 & - \\
\hline $\begin{array}{l}\text { Thyroxine } \\
\text { treated } \\
\text { rats } \\
(2 \mathrm{mg} / \mathrm{kg})\end{array}$ & 10 & 14.0 & 2.2 & $<0.001$ & 3.6 & 0.3 & $<0.05$ \\
\hline
\end{tabular}

* Present address: Department of Pharmacology and Expcrimental Therapcutics, S.P. Medical College, Bikaner, Rajasthan, India. 
ment (7-9) there exists an equalibrium between acetylcholine and catecholamine content of the heart under various experimental conditions. Hence, the increase in acetylcholine level of the heart as observed in the present study may be of a compensatory nature of the clevation of noradrenaline content, of hearts from thyroxine treated animals, as already reported (1). Further, Burn (10) has suggested that the amount of acetylcholine formed in the heart is proportional to its beat rate. Since it is well known that thyroxine increases heart rate $(11,12)$, this factor may also play a role in causing an increase in atrial and ventricular acetylcholine.

Greatful acknowledgement is made to Glaxo Laboratories (India) Pvt. Ltd., for generous supply of 1-thyroxine sodium powder.

\title{
REFERENCES
}

1) Lee, W.C., Lef, C.Y. And Yoo, C.S.: Br. J. Pharmac. Chemother. 25, 651 (1965); 2) Kinguit, R.T.: Anesthesiology 6, 225 (1945); 3) Brewster, W.R., IsAacs, J.P., Osgood, P.F. And King, T.L.: Circulation 13, 1 (1956); 4) Bülerivg, E. ANd Burn, J.H.: J. Physiol. 108, 508 (1949); 5) JoKEL, E.: Heart and Sport 58 Charles S. Thomas, Springfield Illinois (1964); 6) Anand, B.K.: Am. J. Physiol. 168, 218 (1952); 7) Sharma, V.N. and Barar, F.S.K.: Ind. J. Med. Res. 54, 102 (1966); 8) Sharma, V.N. and Parmar, N.S.: Ind. J. Med. Res. 55, 60 (1967); 9) Khanna, N.K. and Madan, B.R.: Arch. int. Pharmacodyr. Thér. 175, 136 (1968); 10) Burn, J.H.: Am. Rev. Pharmac. 9, 1 (1969); 11) Hirvonen, L. And L Lybiacil, H.: Am. J. Physiol. 36, 23 (1956); 12) Thier, M.D., Gravinstein, J.S. and Hoffmann, R.G.: J. Pharmac. exp. Ther. 136, 133 (1962)

\section{NEUROPHARMACOLOGICAL ACTIONS OF TWO NEW ADRENERGIC BETA-RECEPTOR ANTAGONISTS, BUNOLOL AND H 64/52}

\author{
N.K. KHANNA, * R.S. GUPTA, A.K. MATHUR and K. GUPTA \\ Department of Pharmacology and Experimental Therapeutics, \\ Dr. S.N. Medical College, Jodhpur, Rajasthan, India
}

Received for publication November 22, 1971

Some of the beta-adrenergic blocking agents possess marked central nervous depressant and anticonvulsant properties $(1,2)$ while the others induce central nervous stimulation (2). For this reason neuropharmacological actions of two new beta-adrenergic blocking drugs, bunolol (d1-5-[3-(tert-butylamino)-2-hydroxypropoxy]-3,4-dihydro-1-(2H)-naphthalenone hydrochloride) and H 64/52 (p-allyl-phenoxypropanolamine) have been studied as follows:

1) Spontaneous motor activity (SMA): The method described by Vad et al. (3) was employed except for slight modification (4). Twenty-four albino rats of both sexes weighing

* Present addrcss: Department of Pharmacology and Experimental Therapeutics, S.P. Medical College, Bikaner, Rajasthan, India. 